DOI: https://doi.org/10.47405/mjssh.v6i7.918

\begin{tabular}{|c|c|}
\hline 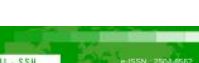 & Malaysian Journal of Social Sciences and Humanities (MJSSH) \\
\hline Malaysian Journal of & Volume 6, Issue 7, July 2021 \\
\hline (MJ-ssH) & e-ISSN : 2504-8562 \\
\hline & $\begin{array}{l}\text { Journal home page: } \\
\text { www.msocialsciences.com }\end{array}$ \\
\hline
\end{tabular}

\title{
Politik Serantau Asia Pasifik Era Pasca Perang Dingin: Kenapa Berbeza dengan Rantau Lain?
}

\author{
Mohd. Noor Yazid ${ }^{1}$ \\ ${ }_{1}^{1}$ Program Hubungan Antarabangsa, Fakulti Sains Sosial dan Kemanusiaan, Universiti Malaysia Sabah (UMS), Kota \\ Kinabalu, Malaysia. \\ Correspondence: Mohd. Noor Yazid (mohdnoor@ums.edu.my)
}

\begin{abstract}
Abstrak
Artikel ini membincangkan perkembangan politik serantau Asia Pasifik dalam era pasca Perang Dingin. Perubahan struktur politik antarabangsa daripada struktur yang bersifat bipolar kepada struktur unipolar telah mempengaruhi struktur politik serantau Asia Pasifik, tetapi perubahan struktur yang berlaku di rantau Asia Pasifik adalah berbeza dengan rantau lain. Perbezaan ini dipengaruhi oleh perbezaan struktur politik serantau yang wujud dalam era Perang Dingin. Dalam era Perang Dingin struktur politik serantau Asia Pasifik adalah bersifat tripolar (didominasi oleh tiga kuasa iaitu Amerika Syarikat, Soviet Union, dan China, 1972-1991). Apabila Soviet Union runtuh dalam tahun 1991, masih wujud dua buah kuasa di rantau Asia Pasifik iaitu Amerika Syarikat dan China. Artikel ini merumuskan bahawa struktur kuasa yang wujud di rantau Asia Pasifik yang berbeza dengan rantau lain adalah dipengaruhi oleh dua faktor iaitu: struktur kuasa yang terbentuk dalam era Perang Dingin (iaitu struktutr tripolar) dan wujudnya kuasa China sebagai kuasa regional yang kuat sejak tahun 1991.
\end{abstract}

Kata kunci: Asia Pasifik, Pasca Perang Dingin, China, Amerika Syarikat, Soviet Union

\section{Regional Politics of the Asia Pacific during Post-Cold War: Why Was it Different with other Regions?}

\begin{abstract}
This article discusses the regional politics of the Asia Pacific region during the post-Cold war era. The changes of the international political structure from bipolarity to unipolarity influenced the Asia Pacific regional structure, but different with other regions. The changes of the Asia Pacific regional structure different with other regions due to the different structure during the Cold War era. During the Cold War period, Asia Pacific was characterized by the tri-polarity structure (The United States, Soviet Union, and China from 1972-1991). When the Soviet Union collapsed in 1991, there were two powers in the Asia Pacific region: the United States and China. This article concludes that the changes of the Asia Pacific during the post-Cold War era was strongly influenced by the regional political structure during the Cold War (tri-polarity structure) and the emergence of China as a strong regional power after 1991.
\end{abstract}

Keywords: Asia Pacific, post-Cold War, China, The United States, Soviet Union 


\section{Pengenalan}

Artikel ini membincangkan perkembangan politik pasca Perang Dingin serta kesannya kepada rantau Asia Pasifik. Rantau Asia Pasifik turut mengalami perubahan akibat daripada berlakunya perubahan struktur politik antarabangsa daripada bipolar kepada unipolar akibat daripada runtuhnya kuasa Soviet Union pada akhir tahun 1991. Perubahan kepada struktur unipolar adalah lebih bersifat umum dan tidak benar-benar tepat dikatakan bahawa Asia Pasifik bersifat unipolar selepas runtuhnya kuasa Soviet Union, khususnya di rantau Timur Laut Asia. Ini dipengaruhi oleh struktur politik serantau yang terbentuk dalam era Perang Dingin yang bersifat tripolar dalam tahun-tahun 1971-1991. Artikel ini membincangkan kenapa perubahan politik yang berbeza berlaku di rantau Asia Pasifik berbanding dengan rantau lain dunia, khususnya dengan perkembangan yang berlaku di benua Eropah. Bagi memahami perbincangan dalam artikel ini, perbincangan tentang struktur tripolar sangat berguna kerana ia mempunyai hubungan rapat bagi menjelaskan kenapa rantau Asia Pasifik tidak benar-benar bersifat unipolar selepas runtuhnya Soviet Union. Apabila Soviet Union runtuh dalam tahun 1991, struktur kuasa di rantau Asia Pasifik tidak berubah kepada unipolar seperti di benua Eropah kerana kewujudan China Komunis sebagai sebuah kuasa besar di rantau Asia Pasifik. Walaupun tidak dinafikan bahawa Amerika Syarikat masih memainkan peranan penting dalam percaturan kuasa di rantau Asia Pasifik dalam era pasca Perang Dingin,namun pengaruh China yang lebih kuat dalam abad ke-21 khususnya selepas tahun 2010 turut mempengaruhi percaturan kuasa politik di rantau Asia Pasifik.

\section{Latar belakang dan kedudukan Kuasa Amerika Syarikat dan China di Asia Pasifik}

Wujudnya kuasa China Komunis di rantau Asia Pasifik telah mempengaruhi percaturan kuasa yang berbeza dengan rantau lain. Asia Pasifik tidak benar-benar bersifat unipolar selepas runtuhnya Soviet Union sebagaimana yang berlaku di benua Eropah. Kedudukan ekonomi dan ketenteraan China Komunis yang semakin maju dan kuat turut mempengaruhi pola percaturan kuasa di rantau Asia Pasifik dalam era pasca Perang Dingin. Struktur kuasa dan pakatan ketenteraan yang dibentuk oleh Amerika Syarikat semasa era Perang Dingin (iaitu perjanjian bilateral dengan Korea Selatan 1953, Jepun 1951 dan Taiwan 1954) tidak dibubarkan dan masih tetap penting dan memainkan peranan tertentu. Kewujudan negara komunis Korea Utara dan tidak berlakunya gabungan negara Korea Utara dan Korea Selatan sebagaimana berlakunya penyatuan Jerman Barat dan Jerman Timur di benua Eropah merupakan suatu fenomena yang berbeza dengan apa yang berlaku di Eropah. Hal ini berlaku kerana ia mempunyai hubungan rapat dengan struktur kuasa sebelum Perang Dingin berakhir, pasca Perang Dingin dan pengaruh kuasa dan peranan yang dimainkan oleh China Komunis di rantau Asia Pasifik.

Operasi Keseimbangan Kuasa (balance of power) dan percaturan kuasa secara keseluruhannya di rantau Asia Pasifik telah menerima kesan dengan berakhirnya Perang Dingin dalam tahun 1991. Tahun 1991 merujuk kepada runtuhnya Soviet Union, walaupun sebenarnya Perang Dingin di benua Eropah berakhir lebih awal daripada runtuhnya Soviet Union 1991 (negara-negara komunis Eropah Timur mulai lemah dalam akhir tahun 1980-an). Negara-negara komunis di Eropah Timur telah runtuh lebih awal iaitu dalam akhir tahun 1980-an. Walau bagaimanapun, keruntuhan Soviet Union pada Disember 1991 dilihat sebagai berakhirnya Perang Dingin apabila negara pemimpin utama komunis, iaitu Soviet Union runtuh secara rasminya.

Politik antarabangsa Asia Pasifik serta bentuk percaturan kuasa yang berlaku mempunyai hubungan yang rapat dengan perubahan bentuk perimbangan kuasa yang berlaku di peringkat antarabangsa, walaupun perubahan politik sepenuhnya tidak berlaku di rantau Asia Pasifik sebagaimana berlaku di benua Eropah. Kekecualian ini berlaku ada hubungannya dengan struktur kuasa di rantau Asia Pasifik yang bukan benar-benar bersifat bipolar sebelum tahun 1991, tetapi sebaliknya bersifat tripolar. Jadi, apabila runtuhnya Soviet Union, China Komunis masih kekal sebagai sebuah kuasa komunis. Selepas tahun 1991 itu sebenarnya, barulah rantau Asia Pasifik lebih bersifat dua kuasa, iaitu dikuasai oleh dua buah kuasa besar utama (iaitu Amerika Syarikat dan China komunis). Walaupun dianggap sebagai sebuah kuasa besar, tetapi peranan dan kedudukan Amerika Syarikat umumnya lebih kuat. ${ }^{i}$ Amerika 
Syarikat mempunyai kedudukan yang lebih kuat dari segi kekuatan ketenteraan dan kedudukan ekonomi. Perbelanjaan ketenteraan Amerika Syarikat dalam tahun 2004 berjumlah USD400 bilion iaitu jumlah yang lebih besar daripada jumlah perbelanjaan semua 15 negara senarai di bawahnya. ${ }^{\text {ii }}$ Kedudukan ekonomi Amerika Syarikat juga masih kuat iaitu peratus KNK yang besar. Walaupun tidak sekuat dalam dekad-dekad awal selepas Perang Dunia Kedua, tetapi sehingga tahun 2004, Amerika Syarikat masih menguasai lebih $25 \%$ daripada KNK seluruh dunia. ${ }^{\text {iii }}$

Kedudukan Amerika Syarikat sebagai kuasa hegemoni akan bertahan kerana ianya disokong oleh empat faktor yang saling kuat-menguatkan di antara satu sama lain iaitu kekuatan ketenteraan (military), kewangan (financial), perdagangan dan ekonomi (trade and economic production) serta tahap penguasaan ilmu (knowledge) seperti yang digambarkan oleh Suzan Strange sebagai sebuah piramid. $^{\text {iv }}$ Keempat-empatnya saling memberikan kekuatan di antara satu sama lain dan memberikan kekuatan kepada kuasa Amerika Syarikat secara keseluruhannya. Jadi, kekuatan kuasa Amerika Syarikat sukar untuk runtuh dalam masa terdekat kerana keempat-empat faktor ini saling bantumembantu dalam mengukuhkan kedudukan Amerika Syarikat sebagai kuasa utama dunia. Jika dilihat dari sudut empat faktor ini, China masih tidak dapat menandingi Amerika Syarikat sebagai kuasa besar di peringkat antarabangsa. Operasi dua kuasa utama ini iaitu China dan Amerika Syarikat di rantau Asia Pasifik juga tidak semua benar dalam semua keadaan serta tidak dipersetujui oleh semua sarjana dalam semua keadaan, tetapi hanya dalam beberapa kawasan dan keadaan tertentu sahaja. Kedudukan China sebagai kuasa berpengaruh di peringkat regional dianggap penting dan perlu disemak dengan teliti oleh Amerika Syarikat dalam sebarang tindakan Amerika Syarikat di rantau Asia Pasifik. Kedudukan Amerika Syarikat dan China di rantau Asia Pasifik sebagai dua kuasa utama yang akan dibincangkan dengan lebih lanjut dalam perbincangan seterusnya.

\section{Bilakah Berakhirnya Perang Dingin?}

Tahun 1991 pada umumnya bolehlah dianggap sebagai satu garis pemisah dan bermulanya satu era baharu dalam struktur dan perkembangan politik antarabangsa. Kenyataan ini dikaitkan dengan kelemahan Soviet Union dan keruntuhan ideologi komunis yang diamalkan oleh negara-negara komunis Eropah Timur dalam tahun 1989. Keruntuhan negara-negara komunis Eropah Timur dalam akhir tahun 1980-an adalah penting bagi perkembangan dan kedudukan pengaruh komunis antarabangsa. Runtuhnya ideologi komunis di Eropah Timur diikuti oleh keruntuhan Soviet Union. Pengaruh komunis di Eropah Timur tidak akan runtuh jika Soviet Union masih kuat kedudukannya. ${ }^{v}$ Keruntuhan negara-negara satelit Soviet Union ini diikuti dengan keruntuhan dan berpecahnya Soviet Union pada bulan Disember 1991.

Proses awal kepada berakhirnya Perang Dingin telah bermula lebih awal daripada tahun ini (1989 dan 1991). Dalam pertengahan tahun 1980-an (tahun 1984 dan 1985) telah berlaku satu krisis politik di Soviet Union. Ketika krisis itu berlaku, Mikhail Gorbachev yang ketika itu menjadi Setiauasaha Agung Parti Komunis dan menerajui kepimpinan Soviet Union. Dalam tahun 1983 dan 1984, Soviet Union menghadapi masalah ekonomi yang teruk akibat daripada kemusnahan hasil-hasil pertanian dan kejatuhan mendadak harga petroleum di pasaran antarabangsa. Kejatuhan harga petroleum dan kemusnahan hasil-hasil pertanian ini membawa ancaman yang besar kepada kedudukan ekonomi dan kekuatan pertahanan Soviet Union secara keseluruhan. ${ }^{\text {vi }}$ Kelemahan ekonomi Soviet Union ini memberi kesan yang besar kepada kedudukan pertahanan Soviet Union yang akhirnya membawa kepada kehancuran Soviet Union.

Kejatuhan Soviet Union ini membawa kepada berakhirnya Perang Dingin yang bermula dan mewarnai politik dunia sejak akhir tahun 1940-an. Mulai tahun 1991 hanya tinggal sebuah kuasa besar sahaja dalam struktur politik dunia iaitu Amerika Syarikat. Mulai tahun-tahun awal keruntuhan Soviet Union, hanya Amerika Syarikat sahaja yang berkuasa dan memainkan peranan yang besar serta berkesan dalam politik dan percaturan kuasa antarabangsa. Hal ini jelas dapat dilihat dalam awal tahun 1990-an dan sepanjang dekad pertama, tetapi mengalami perubahan selepas dekad pertama berakhir. Setelah memasuki dekad kedua berakhirnya Perang Dingin, darjah kekuatan Amerika Syarikat telah mula berubah secara bandingan dengan dekad pertama. 
Perkembangan yang berlaku sejak tahun 2001 berbeza dengan apa yang berlaku dalam dekad pertama pasca Perang Dingin (1991-2001). Peristiwa 11 September 2001 adalah rentetan daripada kelemahan pengaruh Amerika Syarikat selepas dekad pertama pasca Perang Dingin. Pengaruh Amerika Syarikat dalam politik dunia kuat dalam dekad pertama selepas runtuhnya Soviet Union pada akhir tahun 1991 tetapi mula berubah selepas satu dekad, selepas 2001. Kedudukannya telah mula dipersoalkan oleh beberapa buah negara dalam sistem antarabangsa yang tidak berlaku dalam tahun-tahun awal dekad pertama selepas berakhirnya Perang Dingin.

Soviet Union juga telah bangkit semula selepas Boris Yeltsin yang menyokong Barat jatuh. ${ }^{\text {vii }}$ Kenaikan Vladimir Putin sebagai presiden baharu Rusia pada tahun 2000 telah mula mengubah keadaan dan kedudukan Soviet Union daripada awal tahun 1990-an. Dalam hal ini, Peristiwa 11 September 2001 dilihat sebagai sebahagian daripada strategi yang dirancang oleh Amerika Syarikat dalam usaha menguatkan kedudukannya dalam politik dunia menghadapi dekad kedua pasca Perang Dingin. Negara-negara yang difikirkan membawa ancaman kepada Amerika Syarikat akan diserang atas alasan pengganas dan membawa ancaman kepada dunia. Di antara negara yang diserang ialah Afghanistan yang dikatakan bersembunyinya Osama bin Laden yang didakwa oleh Amerika Syarikat sebagai dalang dalam serangan pada 11 September 2001 itu. Pada Oktober 2001, Afghanistan diserang oleh Amerika Syarikat bagi mendapatkan Osama bin Laden yang didakwa berada di Afghanistan. ${ }^{\text {viii }}$ Ada juga pendapat yang merumuskan bahawa objektif sebenar serangan ke atas Afghanistan merupakan strategi mengepung Republik Islam Iran. Dengan menguasai Afghanistan di sebelah timur dan Iraq di bahagian barat, maka Iran akan lebih senang dikepung dan akhirnya dirancang dapat dikuasai oleh Amerika Syarikat.

Strategi ini tidak berjaya kerana pihak Amerika Syarikat gagal menguasai sepenuhnya Afghanistan dan juga Iraq. Iran juga bertambah kuat walaupun dikenakan pelbagai sekatan oleh Amerika Syarikat dan negara-negara sekutu Baratnya. Dalam masa yang sama, Iran bertahan dan berjaya memajukan keupayaan nuklearnya. Hubungan dengan Rusia juga bertambah kukuh sejak lawatan Putin ke Iran pada tahun 2006. Pandangan mengenai Peristiwa 11 September 2001 ini berbeza dengan apa yang diutarakan oleh pihak berkuasa Amerika Syarikat. Bagi Amerika Syarikat, Peristiwa 11 September 2001 merupakan tindakan pihak pengganas Islam. Analisis pengarang ini mengatakan bahawa peristiwa 11 September bukanlah tindakan pihak pengganas seperti yang didakwa oleh pihak Amerika Syarikat. Mengikut hukum Fizik dan kejuruteraan bangunan, adalah tidak mungkin pelanggaran oleh kapal terbang di bahagian atas bangunan Pusat Dagangan Dunia itu dapat meruntuh keseluruhan bangunan dalam bentuk yang sedemikian sifatnya. Bagaimana konkrit dan cerucuk besi bangunan yang begitu kuat dapat dimusnahkan oleh pelanggaran kapal di bahagian atas bangunan. Rumusan yang dapat dibuat ialah peristiwa itu bukan tindakan pengganas Islam sebagaimana yang didakwa oleh pihak Amerika Syarikat, tetapi perancangan tertentu yang dilakukan secara licik dalam strategi pengukuhan kuasa menghadapi dekad ke dua pasca Perang Dingin bagi memastikan Amerika Syarikat kekal kuat pengaruhnya dalam politik dunia.

\section{Ciri-ciri dalam tempoh masa Pasca Perang Dingin}

Struktur politik dunia dalam era pasca Perang Dingin amat berbeza daripada era Perang Dingin. Amerika Syarikat dan bekas Soviet Union (Rusia) tidak lagi berterusan berada dalam keadaan konfrontasi (terutamanya dalam dekad pertama) dan bersaing di antara satu sama lain. Konflik yang berlaku di antara dua buah kuasa besar utama ini yang bermula dalam tahun-tahun akhir 1940-an telah berakhir. Setelah jatuhnya Soviet Union pada bulan Disember 1991, maka pada umumnya hanya tinggal sebuah sahaja kuasa besar utama dalam struktur politik dunia, iaitu Amerika Syarikat. ${ }^{\mathrm{ix}}$

Dua buah pakatan kuasa (organisasi pertahanan) yang dibentuk semasa tahun-tahun awal bermulanya Perang Dingin, iaitu North Atlantic Treaty Organization (NATO) yang dibentuk pada 4 April 1949 dan Warsaw Pact $^{x}$ yang dibentuk pada tahun 1955, telah tidak lagi memainkan peranan sebagaimana peranannya semasa Perang Dingin masih berjalan. Warsaw Pact dibubarkan dalam tahun 1991, tetapi NATO terus berkembang selepas era Perang Dingin berakhir dengan peranan dan keanggotaan yang 
lebih luas. NATO terus berkembang dan memainkan peranan yang lebih meluas selepas berakhirnya Perang Dingin. ${ }^{\mathrm{xi}}$ The Charter of Paris pada 21 November 1990 yang disertai oleh 34 buah negara ${ }^{\mathrm{xii}}$ dengan secara rasminya telah mengisytiharkan berakhirnya Perang Dingin.

\section{Perkembangan Politik Antarabangsa Ekoran daripada Berakhirnya Perang Dingin}

Struktur bipolar yang mewarnai sistem politik antarabangsa sejak hampir setengah abad sebelum ini, iaitu sejak akhir tahun-tahun 1940-an diganti oleh satu struktur baharu yang tidak lagi berpusat kepada dua pusat kuasa utama dunia. Dengan runtuhnya sebuah kuasa besar utama iaitu Soviet Union, kuasa yang masih tinggal hanya kuasa Amerika Syarikat. Pada tahap awal runtuhnya kuasa Soviet Union, struktur politik dunia umumnya boleh dikatakan bersifat unipolar. Hanya terdapat sebuah kuasa utama sahaja yang berkuasa, iaitu kuasa Amerika Syarikat. Kuasa-kuasa lain yang ada, jauh lebih lemah secara bandingan dengan kuasa Amerika Syarikat.

Adalah tidak begitu jelas sampai bilakah kuasa Amerika Syarikat akan terus berupaya menguasai dunia dan sampai bilakah struktur yang dikatakan bersifat unipolar ini akan bertahan?. Kenapa persoalan ini ditimbulkan?. Hal ini kerana ciri-ciri struktur kuasa yang ada pada Amerika Syarikat ini bukanlah bersifat unipolar yang sebenarnya. Perkembangan perjalanan kuasa Amerika Syarikat yang berjalan dalam dekad pertama pasca Perang Dingin, iaitu 1991-2001 selepas keruntuhan Soviet Union lebih diakui sebagai struktur yang bersifat unipolar. Hal ini kerana kuasa Amerika Syarikat dilihat mempunyai kuasa dan pengaruh yang kuat ke atas negara-negara dalam sistem antarabangsa. Akan tetapi, perkembangan serta pengaruhnya berbeza selepas tahun 2001 iaitu selepas peristiwa 11 September 2001, selepas satu dekad berakhirnya Perang Dingin.

Bentuk percaturan kuasa selepas peristiwa 11 September 2001 itu dilihat sebagai bermulanya era baharu struktur unipolar Amerika Syarikat yang telah mula berani disanggah tindakan dan keputusan Amerika Syarikat oleh kuasa-kuasa besar lain dalam sistem antarabangsa. Perang Teluk yang bermula pada 15 Januari 1991 dan serangan Amerika ke atas Iraq pada Mac 2003, dilihat terdapat perbezaan dari segi sokongan kuasa-kuasa besar lain dan pengaruh Amerika Syarikat. Ketika Perang Teluk Januari 1991, kuasa Amerika Syarikat telah mendapat sokongan sebahagian besar negara, khususnya anggota tetap dan anggota tidak tetap Majlis Keselamatan (Security Council) terhadap keputusan tentera bersekutu yang diketuai Amerika Syarikat terhadap keputusan menyerang Iraq bagi pembebasan Kuwait 1991. Ketika itu, Majlis Keselamatan Pertubuhan Bangsa-bangsa Bersatu (Security Council) juga tidak menentang keputusan Amerika Syarikat menyerang Iraq bagi tujuan pembebasan Kuwait. Mikhail Gorbachev ketika itu sedang menghadapi masalah dalam Soviet Union yang serius dan tidak mampu memberi apa-apa keputusan yang bertentangan dengan kehendak Amerika Syarikat. Operasi kuasa berasaskan struktur unipolar berjalan ketika itu kerana Soviet Union benar-benar berada dalam keadaan lemah. Iraq dibawah pimpinan Saddam Hussein telah diberi kata dua, sama ada meninggalkan Kuwait secara aman atau menghadapi serangan oleh tentera pihak bersekutu sekiranya terus berada di Kuwait sehingga 15 Januari 1991. Keengganan Iraq keluar dari Kuwait pada tarikh 15 Januari 1991, telah menyebabkan serangan pihak bersekutu dilakukan ke atas Iraq. Sokongan yang besar oleh negara dunia diberikan kepada tindakan yang diketuai oleh Amerika Syarikat.

Keadaan berbeza ketika serangan kedua Amerika Syarikat ke atas Iraq pada bulan Mac 2003. Sokongan yang diberikan kepada Amerika Syarikat adalah tidak sebagaimana yang berlaku dalam tahun 1991. Majlis Keselamatan Pertubuhan Bangsa-Bangsa Bersatu tidak meluluskan serangan itu dilakukan. Pengaruh Amerika Syarikat telah tidak sekuat seperti dalam tahun awal 1990-an, ketika dekad pertama keruntuhan Soviet Union. Amerika Syarikat mencari jalan lain menyerang Iraq dengan sokongan dan kerjasama negara-negara anggota NATO yang pengaruhnya lebih kuat. Ketika ini, Majlis Keselamatan tidak lagi dapat dikuasai oleh Amerika Syarikat. Dua buah anggota tetap Majlis Keselamatan, iaitu China dan Rusia mempunyai pandangan yang berbeza. Dengan kuasa veto yang ada pada Rusia dan China, Amerika Syarikat gagal mendapat sokongan Majlis Keselamatan (Security Council) dalam serangan ke atas Iraq 2003. 
Dengan perkembangan yang berlaku dalam tahun-tahun selepas akhir 1990-an, konsep unipolar sebenarnya tidaklah begitu tepat kerana struktur yang dikatakan bersifat unipolar adalah merujuk kepada sebuah kuasa yang benar-benar berkuasa (preponderant power) yang tidak dicabar oleh manamana kuasa dan mampu bertindak secara bersendirian. Akan tetapi, Amerika Syarikat selepas satu dekad berakhirnya Perang Dingin tidak lagi menepati ciri-ciri yang dinyatakan sebagai sebuah kuasa unipolar dengan sepenuhnya kerana kadang-kadang kuasa Amerika Syarikat juga telah dicabar oleh beberapa buah negara tertentu seperti China, Rusia dan juga Iran.

Perkembangan berbeza ini berlaku lebih jelas selepas dekad pertama berakhirnya Perang Dingin, iaitu selepas tahun 2001 (Perang Dingin berakhir dengan keruntuhan Soviet Union 1991). Amerika Syarikat juga dilihat gagal menyelesaikan penguraian dan masalah nuklear yang dibangunkan oleh Iran. Cadangan Amerika Syarikat tidak diendahkan oleh Iran. Sekatan ekonomi yang dikenakan oleh Amerika Syarikat dan negara-negara sekutu Baratnya terhadap Iran tidak berkesan. Iran tetap dapat bertahan walaupun banyak sekatan dikenakan oleh Amerika Syarikat dan negara-negara sekutunya. Perkembangan nuklear Iran terus berkembang, manakala kuasa Amerika Syarikat seolah-olah tidak mampu bagi memberikan keputusan yang benar-benar berani terhadap Iran. Hal ini dilihat sebagai kelemahan bagi pihak Amerika Syarikat yang tidak sepatutnya berlaku sedemikian jika Amerika Syarikat adalah sebenar-benar bersifat sebuah kuasa unipolar. Struktur yang terbentuk bukannya bersifat unipolar, iaitu lebih tepat diistilahkan sebagai uni-multipolar; iaitu terdapat sebuah kuasa yang seakan bersifat unipolar (iaitu Amerika Syarikat), tetapi tindakan dan keputusannya dipengaruhi oleh beberapa buah kuasa besar yang seakan bersifat multi-polar (tetapi tidak multi-polar sepenuhnya) kerana sebarang keputusan juga tertakluk kepada Amerika Syarikat. Dalam hal ini, kuasa-kuasa besar lain terikat dengan Amerika Syarikat, manakala kuasa Amerika Syarikat juga terikat dengan kuasakuasa besar lain. Uni-multipolar boleh dianggap sebagai peringkat awal kepada pembentukan struktur multipolar jika kedudukan Amerika Syarikat menjadi semakin lemah, tetapi jika Amerika Syarikat dapat meningkat dan mengukuhkan semula kedudukannya dan dalam masa yang sama kuasa-kuasa tidak meningkat, struktur unipolar sebagaimana pada dekad awal Perang Dingin berakhir akan terbentuk semula.

Tindakan Amerika Syarikat ini ada hubungannya dengan perkembangan yang berlaku di Afghanistan dan juga Iraq selepas peristiwa 11 September 2001. Tindakan Amerika Syarikat terhadap Afghanistan tidak dapat diselesaikan dengan sempurna, begitu juga dengan tindakan Amerika Syarikat di Iraq. Amerika Syarikat menghadapi masalah dalam penyelesaian dan campur tangan politik di Iraq dan Afghanistan. Keadaan penyelesaian politik yang tidak selesai di Iraq dan Afghanistan ini menyukarkan tindakan Amerika Syarikat ke atas Iran. Ada pihak berpendapat bahawa Amerika Syarikat akan menggunakan Iraq dan Afghanistan sebagai asas pangkalan bagi menyerang dan memusnahkan kekuatan Iran. Jika ini benar, bagaimana tindakan ke atas Iran boleh dilakukan jika asas pangkalan (Iraq dan Afghanistan) tidak berjaya dikuasai oleh Amerika Syarikat. Dengan kedudukan yang lemah dan kegagalan menguasai dan mengawal sepenuhnya Iraq dan Afghanistan, maka adalah amat sukar bagi melakukan tindakan seterusnya ke atas Iran.

Struktur antarabangsa kini lebih tepat dikatakan sebagai "unipolar longgar" berdasarkan perkembangan kuasa yang berlaku, khususnya selepas satu dekad berakhirnya Perang Dingin (2001). Dengan perkembangan politik antarabangsa yang berlaku, besar kemungkinan beberapa buah kuasa besar akan muncul dalam politik dunia. Adalah suatu yang tidak mustahil struktur multipolar akan terbentuk dalam masa akan datang dalam struktur politik dunia. Hal ini boleh berlaku jika kuasa Amerika Syarikat menjadi semakin lemah (atau tidak menjadi lebih berkuasa), tetapi dalam masa yang sama berlakunya kebangkitan kuasa-kuasa baharu yang lebih kuat dalam sistem antarabangsa. Kemungkinan berlakunya kebangkitan kuasa China, Iran, Rusia, India, Jerman dan Jepun adalah besar. Struktur yang terbentuk sekarang lebih tepat dikatakan besifat "uni-multipolar" iaitu masih terdapat sebuah kuasa yang mempunyai ciri-ciri unipolar, tetapi dikelilingi dan masih mengambil kira negaranegara kuasa besar lain dalam membuat keputusan.

Kebangkitan dan penekanan semula kepentingan ekonomi dan kerjasama serantau dalam bidang ekonomi dan dalam sesetengah hal menjadi sama pentingnya dengan aspek keselamatan dan ketenteraan. Di sini, berlaku sedikit percanggahan di antara pandangan realist. Isu ketenteraan dan 
keselamatan yang dikatakan sebagai yang sentiasa berada di atas dalam 'list of the international issues', boleh dipertikaikan dalam konteks realiti percaturan kuasa ekonomi dan politik di rantau Asia Pasifik. Hal ini dapat dilihat misalnya dalam realiti kerjasama ekonomi yang berlaku di antara China, Taiwan dan Jepun. Isu ideologi yang berbeza dan persoalan kepentingan keselamatan tidak menghalang negara-negara ini melakukan kerjasama ekonomi dan perdagangan. Kerjasama serantau dalam bidang ekonomi dan kebajikan sosial akan menjadi semakin penting dan mendapat perhatian para pemimpin serantau Asia Pasifik dan juga pemimpin dunia. Walaupun ianya tidak mengatasi kepentingan keselamatan dan ketenteraan, tetapi ia dilihat bukan suatu yang diketepikan. Persoalan 'high politics' dan 'low politics' tidak dipisahkan secara langsung. Dalam hal ini, pandangan realists yang membahagikan 'high politics' dan 'low politics' secara nyata adalah tidak begitu menjadi realiti yang benar-benar tepat dalam konteks politik antarabangsa Asia Pasifik khususnya selepas berakhirnya Perang Dingin.

\section{Kesan Berakhirnya Perang Dingin kepada Rantau Asia Pasifik}

Sebelum membincangkan kesan berakhirnya Perang Dingin kepada rantau Asia Pasifik, beberapa persoalan asas perlu diteliti. Hal ini dirasakan penting kerana ianya mempunyai hubungan rapat dan memudahkan lagi bagi perbincangan persoalan ini. Di antara persoalan yang perlu difikirkan ialah:

i. Persoalan mengenai pola dan struktur kuasa yang terdapat di rantau Asia Pasifik dalam era Perang Dingin. Apakah terdapat perbezaan atau kelainan pola dan struktur kuasa yang terdapat di rantau Asia Pasifik ketika dalam era Perang Dingin belum berakhir.

ii. Perubahan struktur politik dunia dan rantau Asia Pasifik iaitu bagaimana perubahan struktur politik dunia membawa perubahan kepada struktur politik antarabangsa Asia Pasifik?

iii. Perbezaan atau penyimpangan perbezaan di rantau Asia Pasifik akibat daripada tamatnya Perang Dingin. Apakah terdapat kesan atau satu keadaan di rantau Asia Pasifik yang menyimpang daripada apa yang berlaku dalam politik antarabangsa Asia Pasifik akibat daripada tamatnya Perang Dingin?

iv. Struktur selepas Perang Dingin dan kesan kepada rantau Asia Pasifik-bagaimana semua perkembangan politik dunia selepas era Perang Dingin memberi kesan kepada hubungan di antara negara-negara di rantau Asia Pasifik?

\section{Pola Kuasa Antarabangsa Semasa Era Perang Dingin di Rantau Asia Pasifik}

Pola kuasa antarabangsa di rantau Asia Pasifik dipengaruhi oleh kuasa-kuasa besar utama yang memainkan peranan di rantau tersebut. Sebelum berakhirnya Perang Dingin pada tahun 1991, secara umumnya pola kuasa boleh dibahagikan kepada beberapa peringkat seperti berikut:

1. Peringkat pertama iaitu dari tahun 1950 hingga 1960. Pada peringkat ini, percaturan kuasa di rantau Asia Pasifik adalah bersifat bipolar (dua buah kuasa besar utama) iaitu Soviet Union bergabung dengan Republik Rakyat China melawan pihak Amerika Syarikat. Selepas peringkat ini, pakatan dan kerjasama Soviet Union dan China telah berpecah. Republik Rakyat China muncul sebagai sebuah kuasa yang berdiri sendiri.

2. Peringkat kedua adalah dari tempoh masa 1960 hingga 1972. Dalam tempoh masa ini, sebenarnya telah bermulanya unsur-unsur percaturan kuasa yang bersifat tiga pusat kuasa, tetapi ianya belum benar-benar tepat kerana China belum mencapai satu tahap kuasa yang berpengaruh. Dua aspek kelemahan China dapat dilihat, iaitu pertamanya China belum mendapat kembali kedudukannya sebagai anggota tetap Majlis Keselamatan (yang diberikan kepadanya semasa Persidangan Kaherah 1943). China belum lagi dapat menggunakan kuasa veto dalam Majlis Keselamatan. Keduanya, kedudukan fizikal ketenteraan serta teknologi China dalam tempoh masa ini belum lagi kuat. Dalam tempoh masa ini, China bersifat anti-Soviet Union dan juga anti-Amerika Syarikat. Keadaan China 
berubah apabila ia diiktiraf sebagai kuasa veto iaitu anggota tetap Majlis Keselamatan mulai tahun 1972.

3. Peringkat ketiga iaitu selepas tahun 1972 hingga berakhirnya Perang Dingin pada tahun 1991. Dalam tempoh masa ini, pada umumnya hubungan China-Amerika Syarikat adalah lebih baik daripada tempoh masa sebelumnya, tetapi tidak sepenuhnya baik dalam tempoh masa ini. Hal ini kerana hubungan China-Amerika Syarikat ini juga turun naik dan agak kompleks sifatnya. Misalnya ketika Peristiwa Tianamen Square 1989 hubungan agak tegang kerana tindakan menggunakan kekerasan pimpinan Deng Xiaoping terhadap gerakan pro-demokrasi dibantah oleh pihak Amerika Syarikat. Dalam masa yang sama juga hubungan China dengan Soviet Union agak tegang dan kurang baik.

Dalam era Perang Dingin ini, pola percaturan kuasa di rantau Asia Pasifik adalah tidak benar-benar bersifat bipolar, khususnya selepas tahun 1960 apabila pecahnya pakatan dan kerjasama di antara China dan Soviet Union. Pola kuasa di rantau Asia Pasifik lebih tepat dikatakan sebagai bersifat tripolar kerana terdapat tiga kuasa utama yang mempengaruhi percaturan kuasa iaitu Amerika Syarikat, Soviet Union dan Republik Rakyat China. Walaupun kebanyakan sarjana berpendapat bahawa struktur tripolar bermula pada tahun $1972^{\text {xiii }}$ iaitu selepas lawatan Presiden Richard Nixon ke China dan mengiktiraf kuasa besar China dalam Majlis Keselamatan (Security Council) tetapi selepas China berpecah dengan Soviet Union pada awal tahun 1960-an, kewujudan China sebagai sebuah kuasa yang memainkan peranan yang semakin penting di rantau Asia Pasifik telah bermula.

\section{Perubahan Struktur Politik Dunia dan Rantau Asia Pasifik}

Runtuhnya sistem bipolar di peringkat antarabangsa dalam tahun 1991, telah membawa kepada perubahan struktur politik di rantau Asia Pasifik walaupun kesannya agak sedikit berbeza jika dibandingkan dengan perubahan yang berlaku di benua Eropah. Perbezaan struktur kuasa dalam era Perang Dingin dan pasca Perang Dingin di rantau Asia Pasifik turut mempengaruhi kesan yang berlaku selepas berakhirnya Perang Dingin.

Percaturan kuasa di rantau Asia Pasifik dalam era Perang Dingin dimainkan oleh tiga buah kuasa utama, iaitu Amerika Syarikat, Republik Rakyat China dan Soviet Union. Jepun tidak memainkan peranan penting dalam aspek politik dan ketenteraan yang setara sebagaimana tiga kuasa utama di atas, walaupun Jepun mempunyai kekuatan ekonomi yang kuat. Kuasa ekonominya tidak dapat diterjemahkan kepada kuasa politik dan ketenteraan kerana beberapa ikatan yang dilakukan oleh kuasa Amerika Syarikat sejak berakhirnya Perang Dunia Kedua. Perjanjian Keselamatan Amerika SyarikatJepun 1951 dan Perlembagaan Jepun 1947 menentukan peranan Jepun yang terhad dalam aspek politik dan ketenteraan anatarabangsa. Jepun juga bukan sebuah kuasa nuklear. Jepun boleh diistilah sebagai bukan kuasa sebenar (not a real power) iaitu satu kedudukan yang setara antara kekuatan ekonomi dan ketenteraan. ${ }^{\text {xiv }}$ Dalam situasi biasa, sesebuah negara yang mempunyai kedudukan ekonomi yang kuat juga akan mempunyai kekuatan ketenteraan yang kuat. Peratusan yang besar (lebih daripada satu peratus) akan diperuntukkan bagi perbelanjaan pertahanan. Kedudukan Jepun adalah tidak normal kerana perbelanjaan untuk pertahanan Jepun adalah dihadkan kurang daripada satu peratus daripada KDNK Jepun.

Di samping tiga buah kuasa besar utama di atas, bentuk dan kestabilan serantau juga dipengaruhi oleh dua lagi kelompok negara, iaitu ASIAN NIEs (Newly Industrialising Economies) yang terdiri daripada Taiwan, Korea Selatan, Hong Kong dan Singapura; dan juga negara-negara ASEAN khususnya Indonesia, Thailand, Malaysia dan Filipina.

Perkembangan baharu di Indo-China dalam era pasca Perang Dingin yang membawa keadaan relatifnya lebih stabil daripada keadaan sebelumnya telah membawa kesan kepada pautan kerjasama keselamatan dan ekonomi dengan negara-negara anggota ASEAN. Asia Tenggara telah berubah daripada era Perang Dingin, di mana dalam era Perang Dingin, terdapat pembahagian yang jelas iaitu ASEAN dan negara Indo-China Komunis. ${ }^{\mathrm{xv}}$ Perubahan selepas pasca Perang Dingin telah meruntuhkan tembok pemisah di antara negara-negara anggota ASEAN dan negara-negara komunis 
Indo-China. Dalam tahun-tahun era Perang Dingin, pembahagian sempadan ideologi Asia Tenggara adalah lebih jelas, iaitu negara-negara ASEAN mewakili fahaman ideologi demokrasi-kapitalis, manakala negara-negara Indo-China berfahaman ideologi komunis-sosialis. ${ }^{x v i}$ Perdamaian yang berlaku di Kemboja pada awal tahun 1990-an telah memberi kesan kepada kerjasama dengan negaranegara anggota ASEAN. Pada 2 Julai 1992, Vietnam dan Laos telah menandatangani perjanjian persahabatan dan kerjasama dengan negara anggota ASEAN. Vietnam dan Kemboja kemudiannya menganggotai ASEAN.

\section{Kesimpulan}

Perkembangan politik dan percaturan kuasa dalam era pasca Perang Dingin yang berlaku di rantau Asia Pasifik berbeza dengan rantau lain dunia, khususnya dengan perkembangan politik dan percaturan kuasa di benua Eropah. Asia Pasifik tidak berubah secara langsung kepada struktur unipolar akibat daripada runtuhnya kuasa Soviet Union pada tahun 1991 sebagaimana yang berlaku di benua Eropah. Amerika Syarikat menjadi kuasa yang dominan di benua Eropah selepas runtuhnya kuasa Soviet Union. Pengaruh Amerika Syarikat dan perluasan NATO meluas ke negara-negara bekas komunis Eropah Timur. Perkembangan dan perluasan pengaruh Amerika Syarikat ini tidak berlaku di rantau Asia Pasifik. Apa yang berlaku dalam era sebelum pasca Dingin terus berlaku di rantau Asia Pasifik. Wujudnya China sebagai sebuah kuasa yang kuat dan berpengaruh dalam politik serantau Asia Pasifik telah menghalang daripada Amerika Syarikat mempunyai kuasa yang paling berpengaruh di rantau Asia Pasifik. Peranan yang dimainkan oleh Amerika Syarikat di rantau Asia Pasifik adalah berbeza dengan apa yang dimainkan di benua Eropah kerana ianya dihadkan dengan wujudnya kuasa China di rantau Asia Pasifik. Andainya tidak wujud sebuah kuasa yang kuat di rantau Asia Pasifik (iaitu China), maka Asia Pasifik juga akan berlaku perubahan besar dalam percaturan dan struktur baru kuasa politik sebagaimana yang berlaku di benua Eropah. Faktor tripolar yang menguasai struktur kuasa di rantau Asia Pasifik mempunyai hubungan yang rapat dengan kebangkitan China sebagai sebuah kuasa besar dan percaturan kuasa pasca Perang Dingin.

\section{Nota:}

${ }^{i}$ Lihat Singh, Robert. (2012). The United States: the eagle untamed, dalam Murray, Donette and Brown, David (eds.). Multipolarity in the $21^{\text {st }}$ Century: A New World Order, Oxon \& New York; Routledge, hal. 17-47. Singh merumuskan bahawa Amerika Syarikat merupakan negara yang paling penting dalam menyediakan 'public goods' serta banyak masalah di peringkat global masih memerlukan penglibatan serta peranan kuasa Amerika Syarikat. Kesimpulan yang dibuat oleh Robert Singh adalah kedudukan kuasa Amerika Syarikat dalam politik dunia masih belum masih belum mampu dicabar oleh mana-mana kuasa besar lain.

ii Yahuda, Michael. (2004). The International Politics of the Asia-Pacific (second and revised edition), hal. 210.

iii Yahuda, Michael. (2004). The International Politics of the Asia-Pacific (second and revised edition), hal 209-211.

iv Lihat Yahuda, Michael. (2004). The International Politics of the Asia-Pacific (second and revised edition), hal. 101-134 dan 242-280. Perbincangan lebih lanjut tentang saling pergantungan dan kuatmenguatkan di antara satu sama lain di antara ke empat-empat factor ini sila lihat Strange, Suzan, (1994). State and Markets: An Introduction to International Political Economy. London: Pinter, dan juga Strange, Suzan. (1987). The Persistent Myth of Lost Hegemony. International Organization: Vol. 41, hal. 560575.

${ }^{v}$ Lihat Kramer, Mark. (1996). The Soviet Union and Eastern Europe: Sphere of Influence. Dalam Woods, Ngaire. Explaining International Relations since 1945. Oxford, UK: Oxford University Press, hal. 97-125 ${ }^{v i}$ Lihat Hsiung, James, C. (1993). Asia Pacific in The Post-Cold War Order, dalam James C. Hsiung (ed.). Asia Pacific in The New World Politics. Boulder, CO; Lynne Rienner Publishers, hal. 2.

vii Boris Yeltsin berkuasa sebagai presiden Rusia dari 10 Julai 1991 hingga 31 Disember 1999. Vladimir Putin kemudiannya menjadi presiden Rusia.

viii Perkembangan konflik dan peperangan antara Amerika Syarikat dan Afghanistan sila lihat Mohd. Noor Yazid. (2010). The Clash of Civilization di Afghanistan? Amerika Syarikat dan Percaturan Kuasa Pasca Peristiwa 11 September. Jurnal Pemikir, bil.59, (Januari-Mac 2010), hal. 85-100. 


\footnotetext{
${ }^{\text {ix }}$ Hal ini merupakan perkembangan dalam dekad pertama selepas berakhirnya Perang Dingin, tetapi keadaan telah berubah selepas memasuki dekad kedua keadaan menjadi semakin berbeza dalam tahuntahun selepas 2010-an. Contohnya, perkembangan di Urkraine dalam tahun 2014, telah jelas menunjukkan konflik di antara Barat dan Rusia telah mula menjadi isu yang terbuka pertembungannya.

${ }^{x}$ Nama rasmi Warsaw Pact ialah The Warsaw Treaty Organization (WTO) yang dibentuk pada 14 Mei 1955. Walau bagaimanapun, Warsaw Pact lebih sering digunakan secara meluas.

${ }^{x i}$ Lihat Jackson, Robert dan Sorenson, Georg. (2007). Introduction to International Relations: Theories and Approaches. Oxford,UK: Oxford University Press, hal. 81-86.

xii Iaitu negara-negara anggota The Conference on Security and Cooperation in Europe.

xiii Perbincangan tentang struktur tripolar di rantau Asia Pasifik sila lihat Yahuda, Michael. (2004). The International Politics of the Asia-Pacific (Second and revised edition). London \& New York: RoutledgeCurzon. hal.72-97.

xiv Perbincangan tentang kedudukan Jepun sebagai sebuah kuasa yang tidak normal sila lihat Kang, David (2003). Hierarchy and Stability in Asian International Relations, dalam Ikenberry,G. John \& Mastanduno, Michael (eds). International Relations Theory and the Asia-Pacific, New York: Columbia University Press,hal. 174-177. Lihat juga Md. Nasrudin Md. Akhir. (2006). Pertahanan Jepun: Ancaman Senjata Nuklear di Asia Timur. Kuala Lumpur: Penerbit Universiti Malaya; dan Md. Nasrudin Md Akihr (2006). Pertahanan Nasional Jepun: Perikatan Tokyo-Washington dan Keselamatan Asia Timur. Dalam Md. Nasrudin Md. Akhir (ed.). Asia Timur Era Globalisasi: Cabaran dan Masa Depan.Kuala Lumpur: Penerbit Universiti Malaya, hal. 1-43

xv Pembagian dua bahagian Asia Tenggara dalam era Perang Dingin dapat dilihat dengan jelas iaitu negara-negara demokrasi-kapitalis yang pro-Amerika Syarikat atau bukan komunis iaitu anggota-anggota ASEAN (Indonesia, Malaysia, Singapura, Thailand dan Filipina), manakala satu bahagian lagi ialah negara-negara komunis Indo-China. Perbincangan tentang persoalan ini sila lihat Gordon, K. Bernard. (1993). Southeast Asia After the Cold War, dalam James C. Hsiung. Asia Pacific in The New World Politics. Boulder CO: Lynne Rienner Publishers, khususnya hal. 137-142.

xvi Perbincangan lebih lanjut sila lihat, Mohd. Noor Yazid. (2000). Asia Tenggara dan Sistem Bipolar. Jurnal Pemikir, bil. 20, April-Jun 2000, hal. 1-16.
}

\section{Rujukan}

Glaser, Charles, L. (2015). A U.S.-China Grand Bargain? The Hard Choice between Military Competition and Accommodation. International Security, 39(4), 49-90.

Gordon, K. Bernard. (1993). Southeast Asia After the Cold War, dalam James C. Hsiung. Asia Pacific in The New World Politics. Boulder CO: Lynne Rienner Publishers, hal. 137-142

Heginbotham, Eric \& Samuel, Richard, J. (2018). Active Denial: Redesigning Japan's Response to China's Military Challenge. International Security, 42(4), 128-169.

Hsiung, James, C. (1993). Asia Pacific in The Post-Cold War Order, dalam James C. Hsiung (ed.). Asia Pacific in The New World Politics. Boulder, CO; Lynne Rienner Publishers.

Ikenberry,G. John \& Mastanduno, Michael (eds). (2003). International Relations Theory and the AsiaPacific, New York: Columbia University Press

Jackson, Robert dan Sorenson, Georg. (2007). Introduction to International Relations: Theories and Approaches. Oxford, UK: Oxford University Press.

Johnston, Alastair Iain. (2019). China in a World of Orders: Rethinking Compliance and Challenge in Beijing's International Relations. International Security, 44(2),9-60.

Kang, David (2003). Hierarchy and Stability in Asian International Relations, dalam Ikenberry,G. John \& Mastanduno, Michael (eds). International Relations Theory and the Asia-Pacific, New York: Columbia University Press,hal. 174-177

Kramer, Mark. (1996). The Soviet Union and Eastern Europe: Sphere of Influence. Dalam Woods, Ngaire. Explaining International Relations since 1945. Oxford, UK: Oxford University Press, hal. $97-125$

Md. Nasrudin Md. Akhir. (2006). Pertahanan Jepun: Ancaman Senjata Nuklear di Asia Timur. Kuala Lumpur: Penerbit Universiti Malaya

Md. Nasrudin Md Akihr (2006a). Pertahanan Nasional Jepun: Perikatan Tokyo-Washington dan Keselamatan Asia Timur. Dalam Md. Nasrudin Md. Akhir (ed.). Asia Timur Era Globalisasi: Cabaran dan Masa Depan.Kuala Lumpur: Penerbit Universiti Malaya, hal. 1-43 
Mearshiemer, John.J. (2014). The Tragedy of Great Power Politics (updated edition). New York and London: W.W. Norton \& Company.

Mohd. Noor Yazid. (2021). Bipolarity Structure and the Political Development in the East and Southeast Asia. Journal of Xidian University, 15(5), 414-423.

Mohd. Noor Yazid. (2018). Malaysia, Indonesia and the Cold War. Tanjong Malim: Penerbit Universiti Pendidikan Sultan Idris.

Mohd. Noor Yazid. (2013). Hubungan Antarabangsa: Analisis Sistemik dan Domestik. Kota Bharu: Eduserve Resources.

Mohd. Noor Yazid. (2010). The Clash of Civilization di Afghanistan? Amerika Syarikat dan Percaturan Kuasa Pasca Peristiwa 11 September. Jurnal Pemikir, 59 (Januari-Mac 2010), 85-100.

Mohd. Noor Yazid. (2000). Asia Tenggara dan Sistem Bipolar. Jurnal Pemikir, 20, (April-Jun 2000), $1-16$.

Shambaugh, David. (2018). U.S.-China Rivalry in Southeast Asia: Power Shift or Competitive Coexistence? International Security, 42(4), 85-127.

Shambaugh, David \& Yahuda, Michale, (eds). (2014). International Relations of Asia. Lanham: Rowman \& Littlefield.

Singh, Robert. (2012). The United States: the eagle untamed, dalam Murray, Donette and Brown, David (eds.). Multipolarity in the 21 $1^{\text {st }}$ Century: A New World Order, Oxon \& New York; Routledge, hal. 17-47

Strange, Suzan, (1994). State and Markets: An Introduction to International Political Economy. London: Pinter.

Strange, Suzan. (1987). The Persistent Myth of Lost Hegemony. International Organization, 41, 560575.

Welfield, John. (1988). An Empire in Eclipse: Japan in the Postwar American Alliance System. London \& Atlantic Highlands, NJ: The Athlone Press.

Yahuda, Michale. (2019). The International Politics of the Asia-Pacific (fourth and Revised edition). London and New York: Routledge.

Yahuda, Michael. (2004). The International Politics of the Asia-Pacific (Second and revised edition). London \& New York: Routledge-Curzon. 